\title{
Flexural behavior of hybrid GFRP - concrete railway sleepers
}

\section{Comportamento à flexão de dormentes ferroviários híbridos de GFRP - concreto}
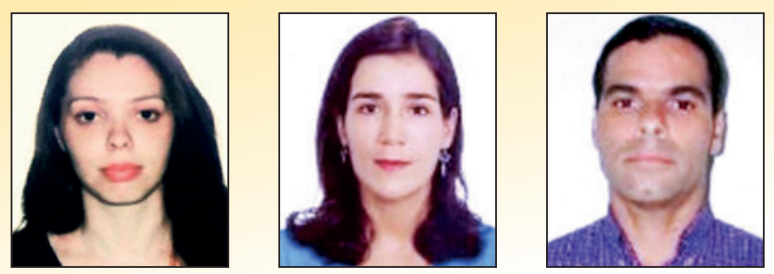

A. C. L. DE AZEVEDO carollopesazevedo@gmail.com https://orcid.org/0000-0002-3777-8241

A. M. A. J. TEXEIRA anam@ime.eb.br https://orcid.org/0000-0003-3762-7192

\section{A. V. CARNEIRO b}

luizcarneiro@id.uff.br https://orcid.org/0000-0001-7036-2048

\begin{abstract}
This paper aims to present the flexural behavior of hybrid GFRP (glass fiber reinforced polymer) concrete beams as sleepers to railway application. It was tried to obtain sleepers with adequate mechanical resistance, not susceptible to corrosion, durable and lighter than the sleepers in prestressed concrete. Pultruded fiberglass and polyester resin profiles were filled with high strength concrete and polyolefin fiber in the following proportions by volume: $1 \%$ and $2.5 \%$. The beams were 1.06 meters long and had a $76 \mathrm{~mm} \times 76 \mathrm{~mm} \times 6 \mathrm{~mm}$ cross section, corresponding to a reduced model in a 1:2.64 scale of a 2.80 meters long sleeper. In the bending tests, the load was applied at the center of the sleeper, as provided in the Brazilian standard NBR 11709 (2015) and American standard AREMA (2016). During the tests the applied load, the vertical deflection and the longitudinal tensile and compression deformations were measured in the center of the span. The influence of fiber addition on the strength, rupture mode and flexural modulus of elasticity of the hybrid beams was analyzed. Finally, the hybrid sleeper performance was compared to that of the prestressed concrete monoblock sleeper. The results obtained were satisfactory, indicating that the proposed hybrid sleeper is a constructively and technically feasible alternative.
\end{abstract}

Keywords: sleeper, concrete, GRFP, polyolefin fiber, experimental analysis.

\section{Resumo}

Este trabalho tem por objetivo apresentar o comportamento à flexão de vigas híbridas de GFRP (glass fiber reinforced polymer - polímero reforçado com fibra de vidro) e concreto para aplicação em dormentes ferroviários. Pretendeu-se obter dormentes com adequada resistência mecânica, não susceptíveis à corrosão, duráveis e mais leves que os dormentes em concreto protendido. Foram estudados perfis pultrudados de fibra de vidro e resina de poliéster, preenchidos com concreto de alta resistência e fibras de poliolefina nas seguintes proporções em volume: $1 \%$ e $2,5 \%$. As vigas tinham 1,06 metros de comprimento e seção transversal de $76 \mathrm{~mm} \times 76 \mathrm{~mm} \times 6,2 \mathrm{~mm}$, correspondendo a um modelo reduzido em escala $1: 2,64$ de um dormente de 2,80 metros de comprimento. Nos ensaios de flexão, a carga foi aplicada no centro do dormente, conforme previsto nas normas ABNT NBR 11709 (2015) e AREMA (2016). Durante os ensaios foram medidas a carga aplicada, a flecha e as deformações longitudinais de tração e compressão no centro do vão. Foi analisada a influência da adição de fibras na capacidade resistente, no modo de ruptura e no módulo de elasticidade à flexão das vigas híbridas. Por fim, o desempenho do dormente híbrido foi comparado ao do dormente monobloco em concreto protendido. Os resultados obtidos foram satisfatórios, indicando que o dormente híbrido proposto é uma alternativa viável construtivamente e tecnicamente.

Palavras-chave: dormente, concreto, GFRP, fibra de poliolefina, análise experimental. 


\section{Introduction}

The sleepers are elements that are positioned at the transverse direction of the axis of the pathway, on which the rails are placed. With the fixture system, they constitute the union element between the ballast and the rail, forming with this the structure of the pathway. The dimensions of the sleeper vary according with the use and the track gauge. The known track gauges are: the broad gauge with 1.60 meters, more used in Brazil, the standard gauge with 1.435 meters and the narrow gauge with 1.00 meter, as shown in Figure 1 (Planeta Ferrovia [1]).

First railways adopted sleepers made of wood (see Figure 2), because this is a material with high mechanical strength and flexibility, which results in a great capacity to withstand the vibrations from the dynamic actions acting on the permanent track (Bastos [2]). Over the years, however, there were disadvantages in the use of wood sleepers, such as: scarcity of noble wood and high need for wood replacement due to time and biological agents, leading to the need to search new technologies. From the Second World War, the countries of Europe, mainly England, France and Germany, began to replace the wooden sleepers by the concrete sleepers (Bastos [2]).

Concrete sleepers can be classified as mono-block or bi-block elements as shown in Figure 3. Bi-block sleepers are reinforced
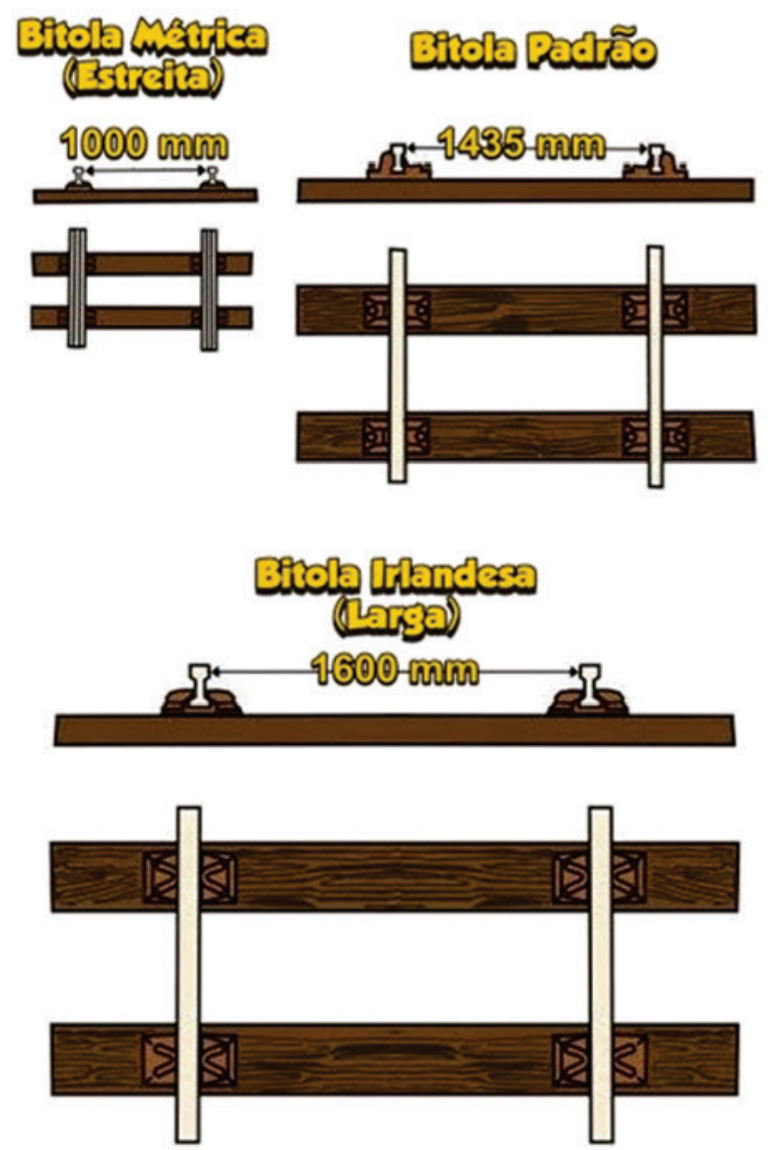

Figure 1

Most used railway gauge, Revista Ferroviária [1] concrete elements interconnected by a metallic profile. The monoblock sleepers are of prestressed concrete because, in general, the tests carried out with reinforced concrete sleepers led to unsatisfactory results. An exception is the reinforced concrete monoblock sleeper designed by Eternit, in Italy, which used cement with asbestos fibers (Bastos [2]). Mono-block sleepers resist higher loads than the bi-block sleepers and have high durability to time and biological agents. However, they are very robust and heavy, usually more than $400 \mathrm{~kg}$ mass. Therefore, it is necessary to use heavy machinery for the transportation and installation of these sleepers. Besides, the construction and the demobilization costs of sleeper factory near the railway site are quite high.

The steel sleepers have longer service life than the wood sleepers, high mechanical resistance and are lightweight (around $70 \mathrm{~kg}$ mass) (Trindade [3]). According to DNIT [4], the steel sleepers are easy to settle, but their lightweight is inconvenient for heavy traffic lines. The steel sleepers also have low corrosion resistance, requiring proper treatment for its mitigation. They are also electrical conductors, requiring the installation of insulation in the rail/ sleeper interface.

This work presents and analyzes test results of pultruded glass fiber reinforced polymer (GFRP) sleepers filled with concrete, without or with polyolefin fibers addition to the mass, in a reduced model with 1.06 meters length. The authors also extrapolate the experimental results for a prototype of 2.80 meters length and compared their resistance capacity and their weight with that of a mono-block prestressed concrete sleeper, usually adopted in Brazilian railways.

The association between concrete and pultruded glass fiber polymer profile aims to reduce or even eliminate the main problems of the railway sleepers, which are: the high weight in the case of sleepers in concrete, corrosion susceptibility in the case of steel sleepers and low resistance to biological agents in the case of wood sleepers. The addition of polyolefin fibers to the concrete is intended to increase the resistance to the traction and to delay the opening of cracks. Polyolefin fiber is not subject to corrosion

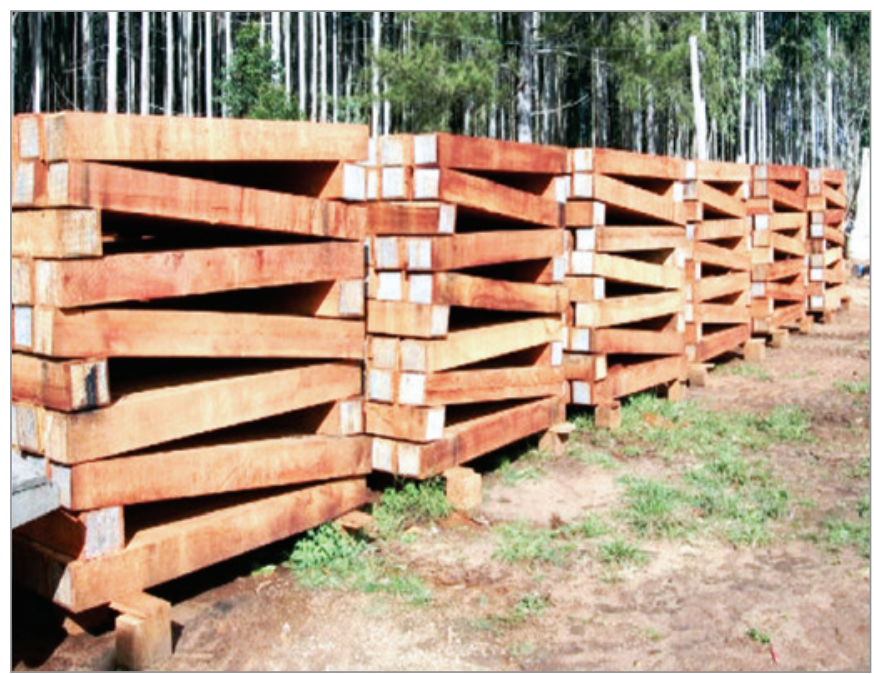

Figure 2

Wood sleeper, Mundo dos Trilhos [20] 
and is lighter than steel fiber, whose addition to concrete is already widespread worldwide.

Research found in the literature on the Association of Concrete to the Pultrudado profile of fiberglass and resin for application in beams and research on the addition of polyolefin fibers to the concrete are presented below.

\section{Theoretical reference}

\subsection{Fiber reinforced polymer}

The fiber reinforced polymer is a composite material formed by combining two materials, one being the reinforcement in synthetic fibers and the other the polymer matrix. The combination of materials enables the composite to achieve properties that individually the materials would not reach. (Gibson [5])

The main synthetic fibers are glass, carbon and aramid. The glass fibers are the cheapest and therefore the most used fibers in the manufacture of composite materials. There are several processes of manufacturing composite materials among which stands out the pultrusion. Such process gives the product distinct characteristics, therefore, the quantity and orientation of the fibers have influence on the physical and mechanical properties of the composite material and its production cost. The pultrusion enables the fabrication of constant cross-section profiles. It consists of the "pulling" of resin-impregnated fibers, through a heated metallic mold, producing profiles with high mechanical properties in the direction of the fibers, at a low cost and immune to corrosion.

\subsection{Association between pultruded profiles and concrete for application in beams}

Studies proposing the association between pultruded profiles and concrete for application in beams were recently published

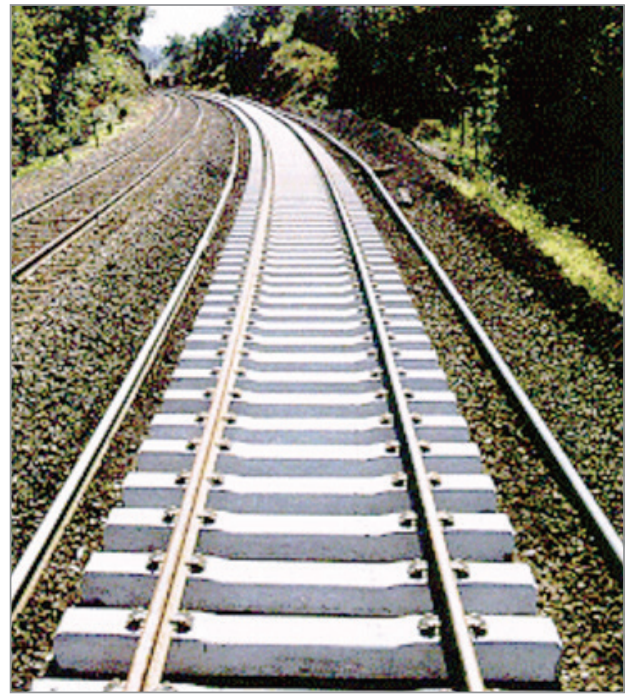

(a) and come arousing the interest of researchers and companies. Ferdous et al. [6] investigated the feasibility of applying a hybrid beam of pultruded GFRP and geopolymeric concrete as sleepers for railways. The compressive characteristic strength of the geopolymeric concrete and the Portland cement concrete were, respectively, $40 \mathrm{MPa}$ and $57 \mathrm{MPa}$. The square tubular profiles had dimensions of $190 \mathrm{~mm} \times 100 \mathrm{~mm} \times 10 \mathrm{~mm} \times 2000 \mathrm{~mm}$ long. The experimental and computer simulation results obtained showed that the rupture of the hybrid beam occurred due to the crushing of the concrete in the compressed region. The vertical displacement results and the pressure on the ballast of the sleeper were similar to those obtained in traditional wood sleepers, which increases the possibility of acceptance of this type of sleeper in light rail transport.

Muttashar et al. [7] also studied the influence of the concrete on the bending of hybrid beams formed by concrete-filled pultruded GFRP square tubes. The GFRP profiles had dimensions of 125 $\mathrm{mm} \times 125 \mathrm{~mm} \times 6.5 \mathrm{~mm} \times 2000 \mathrm{~mm}$ long filled with concretes with average compressive strength of $10 \mathrm{MPa}, 37.5 \mathrm{MPa}$ and $43.5 \mathrm{MPa}$. They verified that the concrete-filled profiles resisted a load $100 \%$ to $140 \%$ higher than the hollow profiles and had a $25 \%$ increase in rigidity. The increase in the compression strength of concretes (from $10 \mathrm{MPa}$ to $43.5 \mathrm{MPa}$ ) increased the failure load by $19 \%$ and practically did not change the flexural stiffness of the beam.

Muttashar et al. [8] studied the bending behavior of multicellular pultruded GFRP beams filled partially with concrete. For this, they glued GFRP square tubes with dimensions of $125 \mathrm{~mm} \times 125 \mathrm{~mm}$ $x 6.5 \mathrm{~mm}$ with epoxy adhesives, forming beams with one to four cells, with lengths of $2000 \mathrm{~mm}$ (single-cell), $2750 \mathrm{~mm}$ (two cells), $3700 \mathrm{~mm}$ (three cells) and $5000 \mathrm{~mm}$ (four cells). The authors used concretes with compression resistances of $15 \mathrm{MPa}$ and $32 \mathrm{MPa}$ to fill the upper cell of the multicellular beams. The beams were tested in bending and their behaviors were compared to those of hollow beams. The results showed an increase of up to $27 \%$ in the resistance of the multicellular beams when compared to the beams

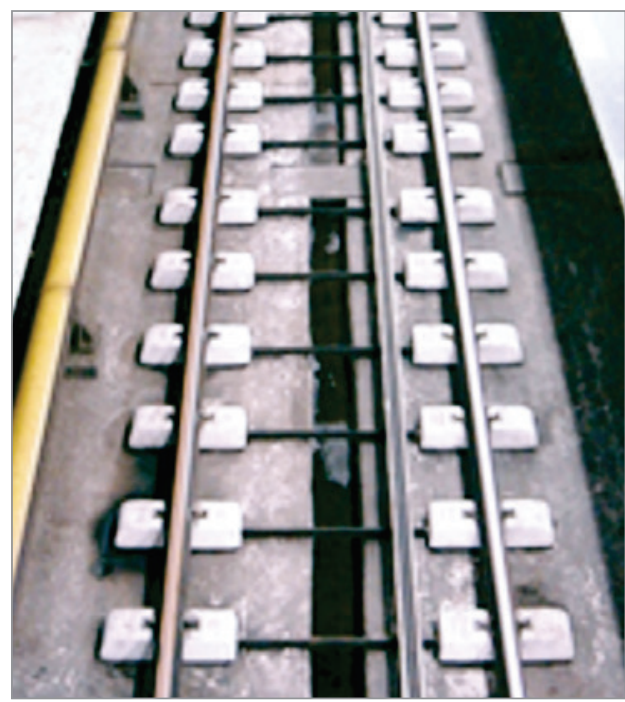

(b)

Figure 3

Pathway: (a) mono-block sleeper, PANDROL [21] e (b) bi-block sleeper, Revista Ferroviária [1] 

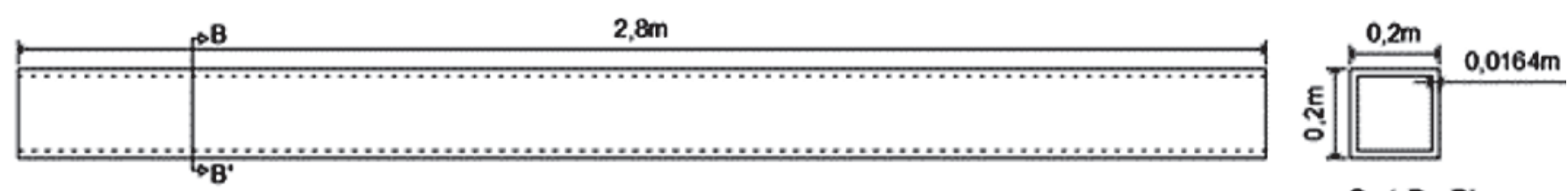

Cut B-B'

\section{Figure 4}

Longitudinal view and cross section of the prototype GFRP (Author)

of a single cell. The filling of the upper cell of the beams with concrete increased the load capacity and the stiffness of the beams. The multicellular GFRP beams filled with concrete in the upper cell failured with $38 \%$ to $80 \%$ higher load and presented $10 \%$ to $22 \%$ higher stiffness than the corresponding hollow multicellular beams. The increase in the concrete compression strength of the beams, from $15 \mathrm{MPa}$ to $32 \mathrm{MPa}$, resulted in an increase of up to $14 \%$ in the failure load.

\subsection{Addition of polyolefin fiber to concrete}

Gaspar, Carneiro and Teixeira [9] studied the addition of steel fiber and polyolefin fiber in concretes subjected to ballistic impact. The authors tested 28 square plates with dimensions of $300 \mathrm{~mm} \times 150$ $\mathrm{mm} .14$ plates were molded with conventional concrete resistance and 14 other plates were molded with high-strength concrete. The volumetric contents of fibers were $0 \%, 0.5 \%, 1.0 \%$ and $1.5 \%$. For the ballistic test $7.62 \mathrm{~mm}$ caliber projectiles were used to check the shielding capacity and the level of damage on each concrete plate. The results indicated that the addition of steel fibers and polyolefin fibers favored the increase of the initial concrete compressive strength, the shielding capacity and the reduction of damage caused by the impact.

Alberti et al. [10] and Alberti et al. [11] studied the difference in the orientation and density of polyolefin fibers added to the mechanical vibrated concrete and self-consolidating concrete. Fibers with 60 $\mathrm{mm}$ and $48 \mathrm{~mm}$ long were added to the concrete in the proportion of $9 \mathrm{~kg} / \mathrm{m}^{3}$, which is equivalent to $1.0 \%$ in volume. Samples with dimensions of $150 \mathrm{~mm} \times 150 \mathrm{~mm} \times 600 \mathrm{~mm}$ were molded and tested in bending. The concrete characteristic compressive strength varied from 32.9 MPa to $39.3 \mathrm{MPa}$. The self-consolidating concrete samples presented more uniform distribution of the fibers, as well as the samples with fibers of $48 \mathrm{~mm}$ long showed better orientations. The authors concluded that polyolefin fibers can meet the requirements of the standards, contributing in reducing the postpick load cracking of the structural element. They also verified that while the length of the fiber, the type of concrete and the sample dimensions influence the fracture surface, the positioning and orientation of the fibers throughout the piece can be quite relevant on the performance of the structural element.

\section{Materials and methods}

\subsection{Sleeper design}

The design of a sleeper must meet the requirements of the technical standards. The specific Brazilian standard for concrete sleepers is the ABNT NBR 11709 [12]. ABNTs design methodology [12] it's very similar to AREMA [13]. This is because the characteristics of the Brazilian pathways, with regard to the type of transport and the quality of maintenance, are similar to the American pathways. The design methodology of ERRI, described in CEN (1996), leads to lighter and less resistant sleepers than the sleepers designed according to the American standard. (Bastos [2])

\subsection{Sleeper prototype design}

The sleeper prototype is composed of a pultruded GFRP square tube filled with concrete with average compressive strength of 73 $\mathrm{MPa}$. Considering the dimensions of the shoulder pads of the prestressed concrete sleeper, profiles with $200 \mathrm{~mm} \times 200 \mathrm{~mm} \times 16.4$ $\mathrm{mm}$ was chosen, as presented in Figure 4 . The length of 2.80 meters is usual for prestressed concrete sleeper in Brazil, so it was adopted in this project. Figure 5 shows the schematic design of the GFRP /concrete hybrid sleeper. It should be emphasized that, according to ABNT NBR 11709 [12], the concrete characteristic compression strength of sleepers may not be less than $45 \mathrm{MPa}$. GFRP present high tensile strength in the direction of the fibers and low specific weight. The GFRP filled with concrete aims to increase the stiffness and the resistance to bending and shear of the beam. Therefore, the association between the GFRP and concrete can be a good alternative to obtain mono-block

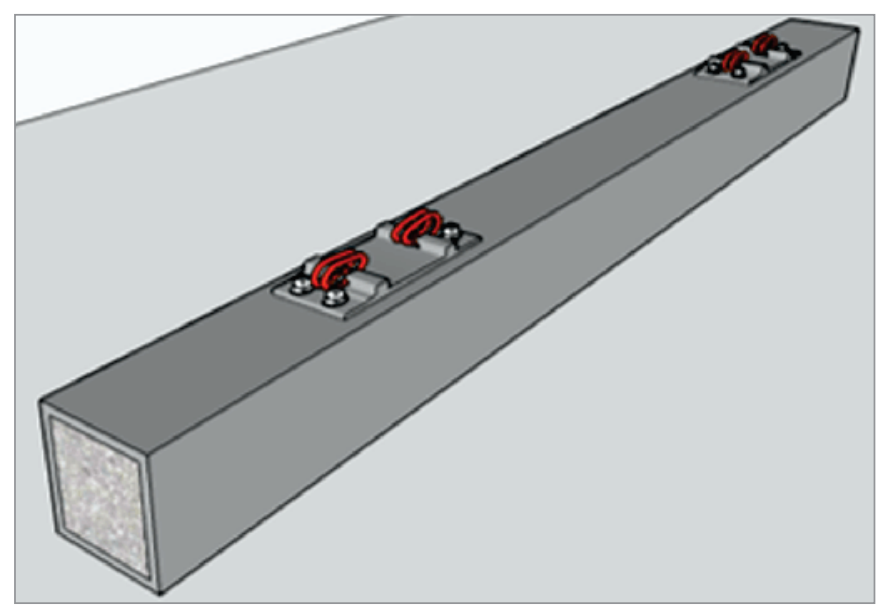

Figure 5

Schematic drawing of GFRP/concrete hybrid sleeper (Author) 

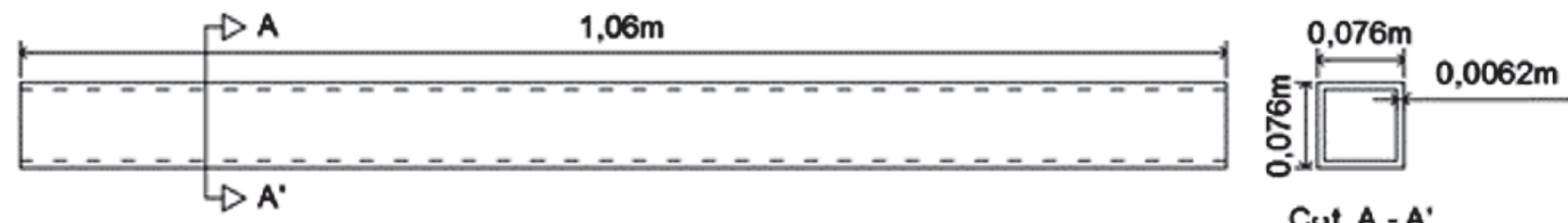

Cut $A-A^{\prime}$

\section{Figure 6}

Longitudinal view and cross section of the GFRP profile of the reduced model (Author)

sleeperslighterthanthe prestressed concretemono-blocksleepers. The GFRP square tubes are usually manufactured and traded in the Brazilian market, but with transverse section dimensions smaller than $200 \mathrm{~mm} \times 200 \mathrm{~mm}$. Therefore, it was decided to study a reduced model of the sleeper, using the profiles dimensions available in the market.

\subsection{Reduced sleeper model design}

For the design of the reduced sleeper model, the theory of the similarity of the physical models was applied, which allows a reduced model of structure to reproduce the behavior of the prototype. For this, the dimensional analysis of the deformation problem was done according to Carneiro [14] and the following representative $\pi$ numbers were obtained to the problem. This numbers should be equal in the reduced model and in the prototype.

$\Pi_{1}=\frac{\mathbf{F}}{\mathbf{E l}^{2}}=\mathbf{N}_{\mathbf{H o}}$

$\Pi_{2}=\frac{\gamma \mathbf{l}}{\mathbf{E}}=\mathbf{N}_{\text {Gal }}$

$\Pi_{3}=\frac{\boldsymbol{\delta}}{\mathbf{l}}$

$\mathrm{F}$ is the force applied;

$E$ is the longitudinal Young's modulus of the material;

$\mathrm{I}$ is the length of the sleeper;

$\gamma$ is the specific weight of the material and

$\delta$ is the vertical displacement of the sleeper.

The parameter $\pi_{1}$ is known as Hooke's number. It is applied to materials with linear elastic behavior in which tensions are proportional to deformations, as shown in Teixeira [15]. With the number $\pi_{1}$ and the force in reduced model, the force in the prototype is obtained according to equation (5). As the material of the reduced model is equal to the material of the prototype, it isn't possible to respect directly the number $\pi_{2}$. To attend it indirectly, it is necessary to add mass to the reduced

\section{Table 1}

Scale factors of the reduced model

\begin{tabular}{cc}
\hline Magnitude & Scale factor \\
\hline Vertical displacement & $1 / 2,64$ \\
Profiles area & $1 /(2,64)^{2}$ \\
Dead load & $1 /(2,64)^{3}$ \\
Applied load & $1 /(2,64)^{2}$ \\
Additional mass & 1,64 \\
\hline
\end{tabular}

model. So, the specific weight of the prototype $\left(\gamma_{p}\right)$ is equal to the apparent specific weight of the reduced model $\left(\gamma_{m}\right)$ multiplied by the relationship between the reduced model length and the prototype length, according to the equation (6). The mass to be added to the reduced model should be equal to $\left(\frac{l_{p}}{l_{m}}-1\right)$ times the mass of the reduced model.

From the number $\pi_{3}$, it is obtained the vertical displacement in the prototype, that is the vertical displacement of the reduced model multiplied by the relationship between the length of the prototype and the length of the reduced model, as shown in equation (4).

$\delta_{p}=\frac{\delta_{m} \mathrm{l}_{m}}{\mathrm{l}_{p}}$

$\delta_{p}$ is the vertical displacement of the prototype;

$\delta_{m}$ is the vertical displacement of the reduced model;

$I_{p}$ is the length of the prototype and;

$I_{m}$ is the length of the reduced model.

$\mathrm{F}_{\mathrm{p}}=\frac{\mathrm{F}_{\mathrm{m}} \mathrm{l}_{\mathrm{p}}^{2}}{\mathrm{l}_{m}^{2}}$

$F_{p}$ is the force applied in the prototype and;

$F_{m}$ is the force applied in the reduced model.

$\gamma_{\mathrm{p}}=\frac{\gamma_{\mathrm{m}} \mathrm{l}_{\mathrm{m}}}{\mathrm{l}_{\mathrm{p}}}$

$\gamma_{p}$ is the specific weight of the prototype and;

$\gamma_{m}$ is the apparent specific weight of the reduced model.

The scale of the reduced model was defined from the availability of profiles in the Brazilian market. The largest available square profile was adopted, which had $76 \mathrm{~mm} \times 76 \mathrm{~mm} \times 6.2 \mathrm{~mm}$, as shown in Figure 6 , resulting in a geometric scale factor between the prototype and the reduced model (Ip / Im) of 2.63.

The scale factors of the reduced model in relation to the prototype are presented in Table 1.

\subsection{Experimental program}

Seven GFRP/concrete hybrid beams were prepared. Two hybrid beams were of plain concrete, four were of concrete with the addition of $25 \mathrm{~mm}$ polyolefin fibers (two with $1 \%$ in volume and two with $2.5 \%$ in volume) and one beam was of concrete with the addition of $1 \%$ in volume of $35 \mathrm{~mm}$ polyolefin fibers.

12 cylindrical concrete samples with dimensions of $150 \mathrm{~mm} \times 300 \mathrm{~mm}$ were also concreted. Three samples were of plain concrete, seven 


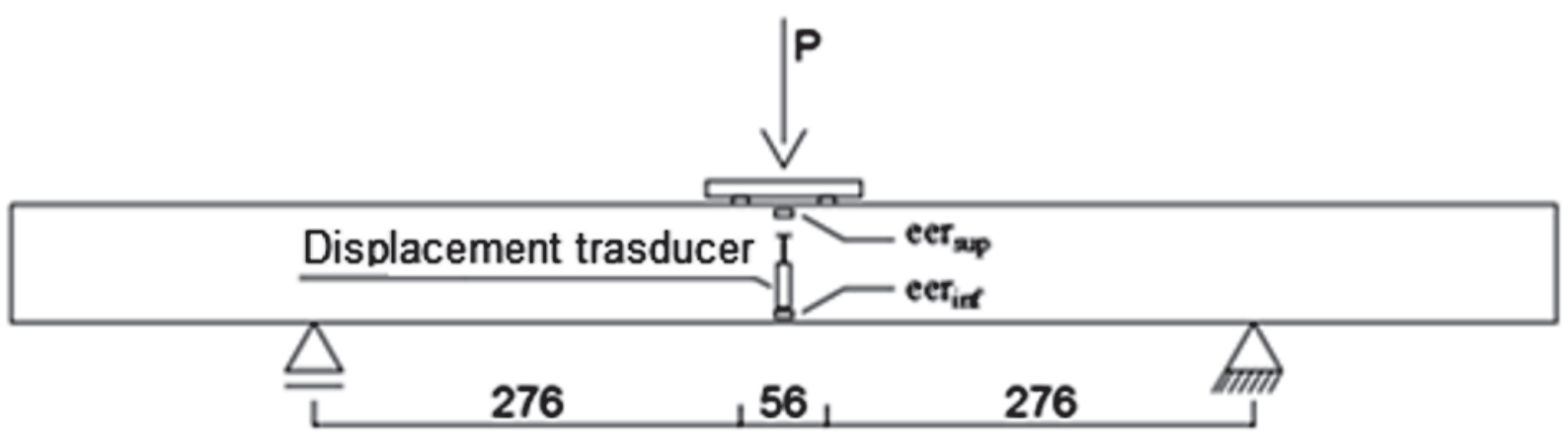

Dimension in $\mathrm{mm}$

\section{Figure 7}

Structural scheme and beam instrumentation (Author)

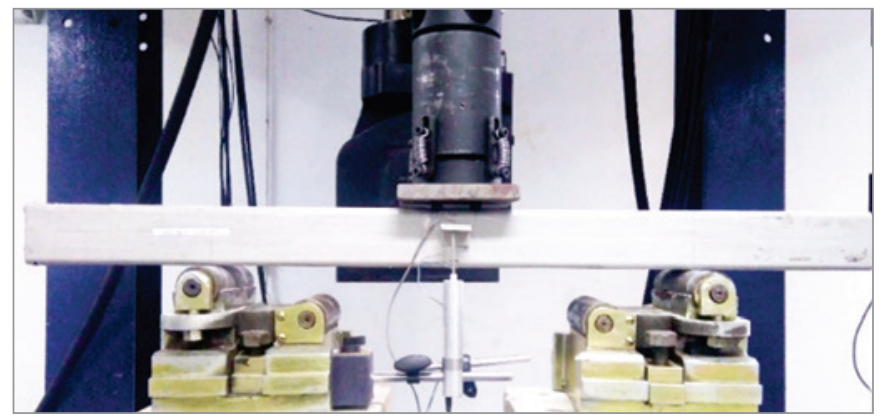

Figure 8

Reduced model of the hybrid sleeper at the beginning of the test (Author)

samples were of concrete with the addition of $25 \mathrm{~mm}$ polyolefin fibers (four with $1 \%$ in volume and three with $2.5 \%$ in volume) and two samples were of concrete with $1 \%$ addition in volume of $35 \mathrm{~mm}$ polyolefin fibers. It was also molded a $100 \mathrm{~mm}$ x $200 \mathrm{~mm}$ cylindrical sample with $1 \%$ addition in volume of $25 \mathrm{~mm}$ polyolefin fibers. 14 concrete beams were also molded. Four beams had $1 \%$ and four beams had $2.5 \%$ addition in volume of $25 \mathrm{~mm}$ polyolefin fibers. Three beams were of plain concrete and other three beams had $1 \%$ addition in volume of $35 \mathrm{~mm}$ polyolefin fibers. All concrete beams were molded with the same length of the reduced model sleeper and with the internal dimensions of the GFRP $(63,6 \mathrm{~mm} x$ $63,6 \mathrm{~mm} \times 1060 \mathrm{~mm}$ ).

Samples of GFRP for tensile tests and for determination of the specific weight and the mass fraction of fiber were also prepared. All the samples and beams were molded and tested at the Building Materials and Concrete Laboratory of the Military Engineering Institute (IME).

The tensile tests of the GFRP samples were carried out in accordance with the ASTM D297 [16] e ASTM D3039/D3039M [17]. The axial compression tests of the cylindrical samples were carried out according to ABNT NBR 5739 standard [18].

The hybrid beams were instrumented with two strain gauges (type KFG-5-120-C1-11 and Kyowa brand) on the upper and lower surfaces of the GFRP profile, in the center of the test span. One displacement transducer with $50 \mathrm{~mm}$ course, type DTH-A-50, Kyowa brand, was used to measure the vertical displacement in the center of the span. The structural and instrumentation scheme of the beams is shown in Figure 7.

The hybrid beams were tested in bending and steel rollers were adopted in the supports, as presented in Figure 8. The load was applied at a rate of $22 \mathrm{kN} / \mathrm{min}$ with a hydraulic actuator of MTS brand and load capacity of $1000 \mathrm{kN}$. The acquisition of the loads and the vertical displacements throughout the tests was carried out with the

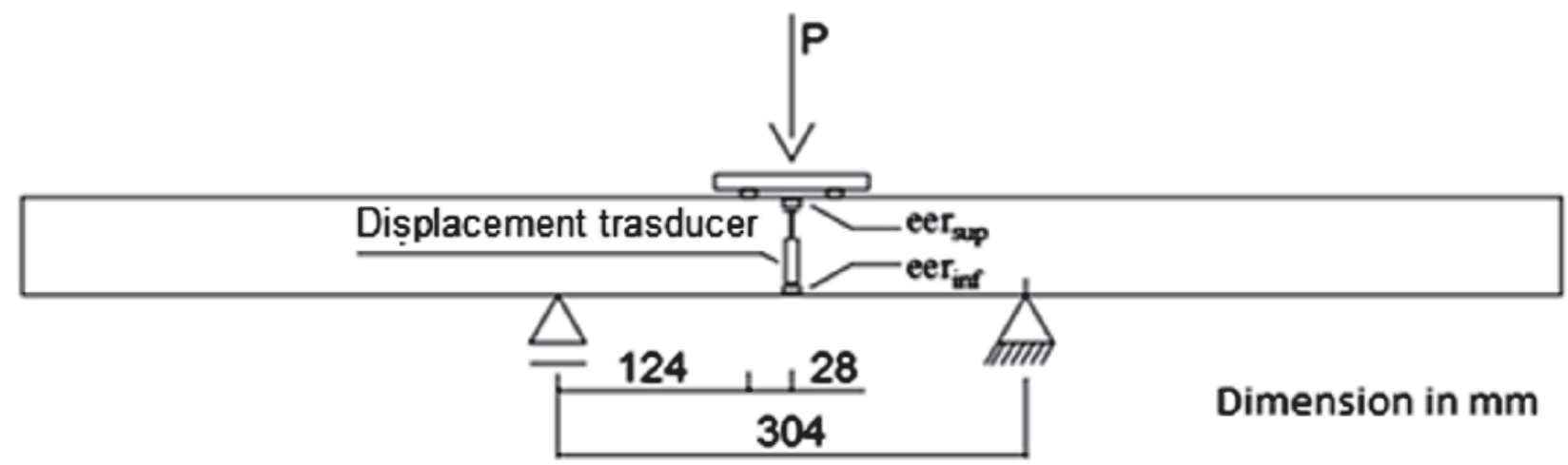

Figure 9

Structural and instrumentation scheme of the concrete beams (Author) 


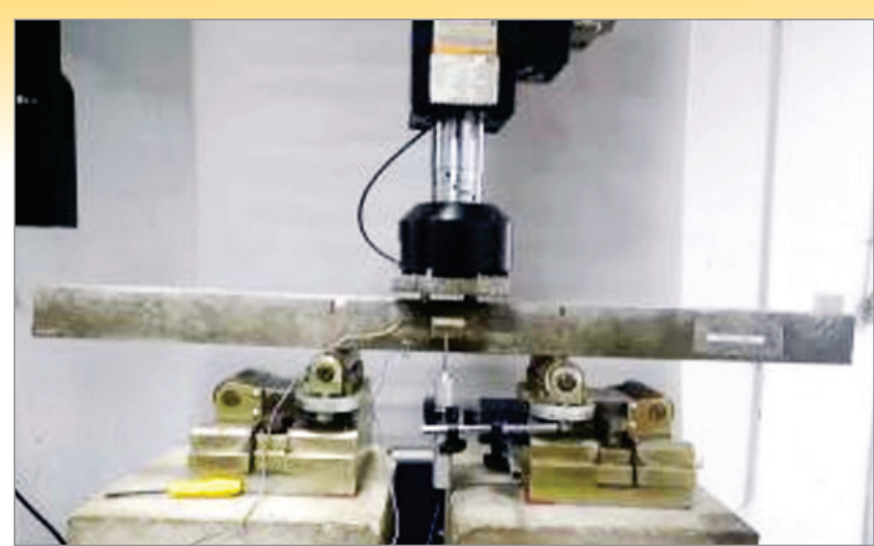

Figure 10

Beam before bending test (Author)

Flextest system, also from MTS brand. The acquisition of the deformations was done with the ADS 2000 system, from Lynx brand. The concrete beams with volumetric variation of fibers were instrumented with two strain gauges (eer ${ }_{\text {sup }}$ and eer ${ }_{\text {inf }}$ ) type KC-80120-A1 - 11, Kyowa brand, and one displacement transducer, type DTH-A-50 and Kyowa brand, as shown in Figure 9. The beams were tested in bending with a hydraulic actuator of MTS brand and load capacity of $50 \mathrm{kN}$, as presented in Figure 10. The acquisition of the loads, vertical displacements and deformations were done with the same equipments of the hybrid beams tests.

\section{Results and analysis}

\subsection{Reduced model test results}

Table 2 presents the mass fractions of total fibers $\left(\mathrm{V}_{\mathrm{f}}\right.$ total \%) and long fibers $\left(\mathrm{V}_{\mathrm{f}}\right.$ long $\left.\%\right)$, the specific weight, the failure strength $\left(\sigma_{\text {rup }}\right)$, the failure deformation $\left(\varepsilon_{\text {rup }}\right)$ and the Young's modulus obtained in the tensile tests performed with GFRP samples. The GFRP presents linear behavior and fragile failure.

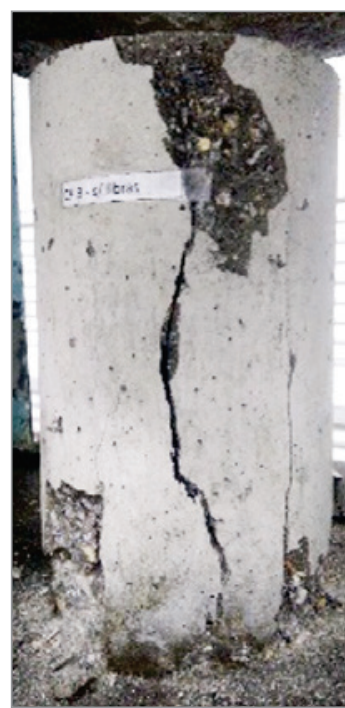

(a)

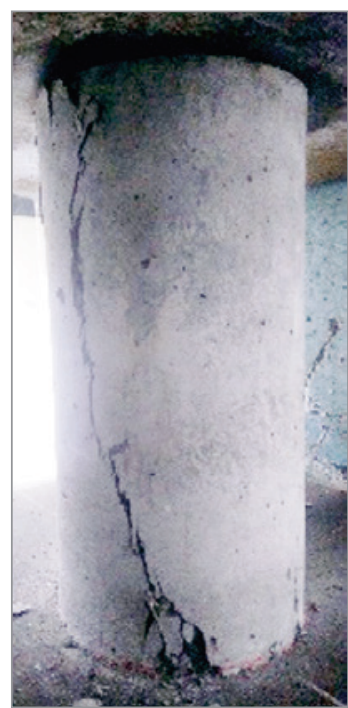

(b)

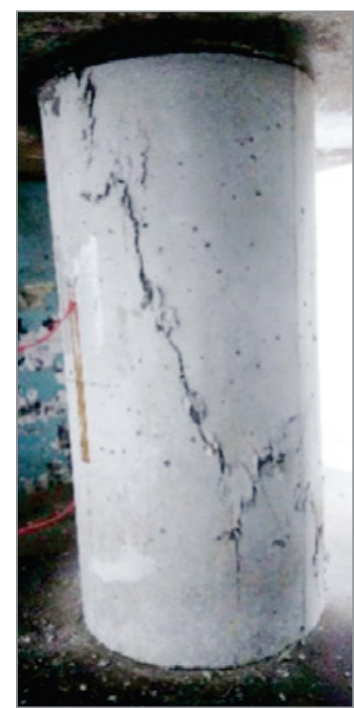

(c)

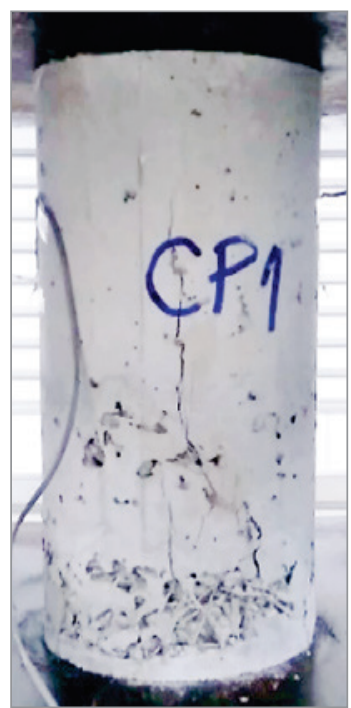

(d)

Figure 11

Specimens after compression tests: (a) plain, (b) with $1 \%$ fibers $(25 \mathrm{~mm})$, (c) with $2.5 \%$ fibers $(25 \mathrm{~mm})$ and $1 \%$ fibers $(35 \mathrm{~mm}$ ) (Author) 


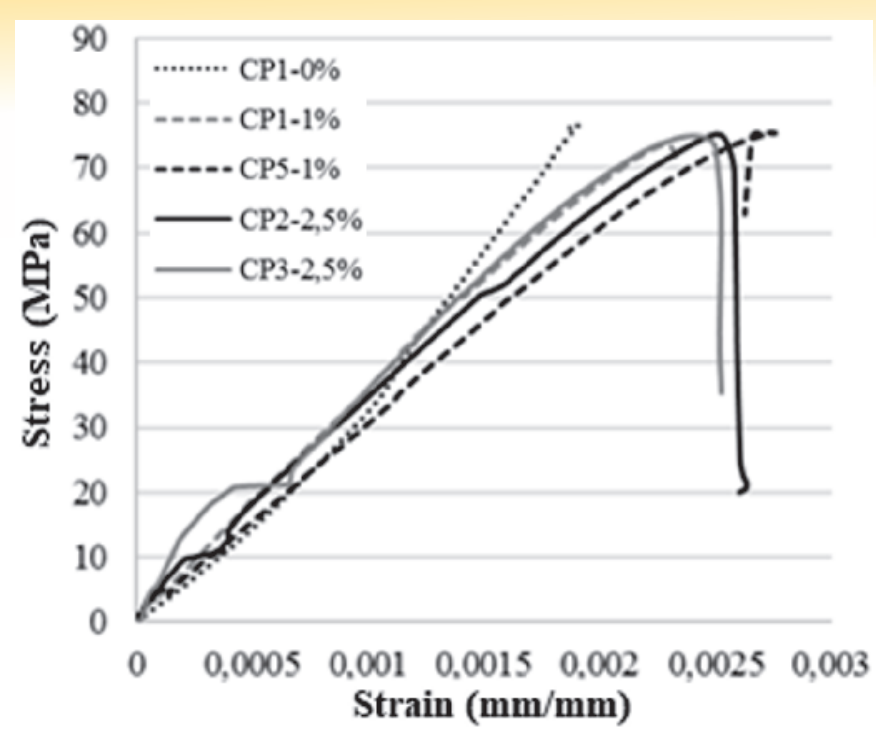

Figure 12

Stress $x$ strain curves of the concrete specimens after compression tests (Author)

compressive strength of the specimens with $1 \%$ of fibers of 35 $\mathrm{mm}$ was much lower than of the specimens with $1 \%$ of fibers of $25 \mathrm{~mm}$. This occurred due to the large number of voids in the specimens (see Figure 11).

Table 4 displays the average failure values of load, vertical displacement and stress (on the upper and lower edges) of the concrete beams and the average compressive and tension failure strength of the corresponding cylindrical concrete samples.

The results of load, vertical displacement and strain (on the upper and lower edges of the GFRP profile) obtained in the hybrid beams tests are presented in the Table 5. The typical failure of the hybrid beam is shown in the Figure 13.

The failure of the hybrid beams occurred on the lower edge and was due to the failure of the concrete by shear followed by the failure of the GFRP profile parallel to the fibers. The smallest failure

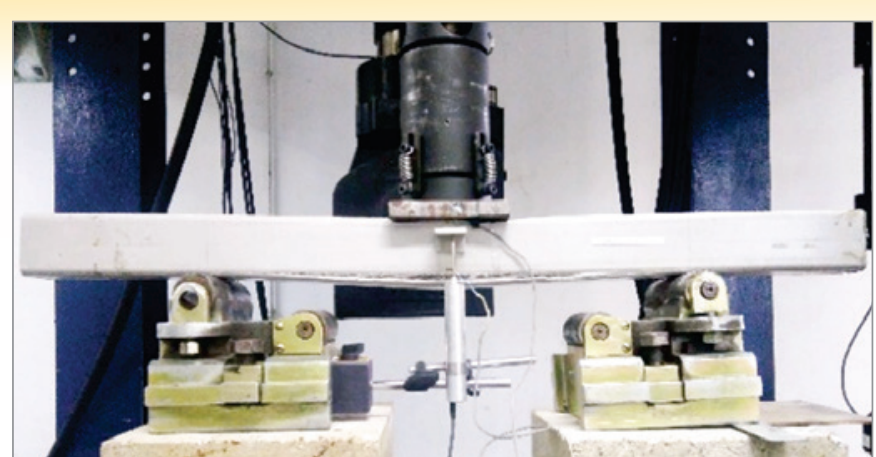

Figure 13

Hybrid sleeper reduced model after failure (Author)

load of the hybrid beam with $1 \%$ fibers of $25 \mathrm{~mm}$ long is due to the smaller compressive strength of the concrete of these beams.

Figure 14 and Figure 15 present the load $x$ vertical displacement and load $x$ strain curves of the hybrid beams, respectively. All hybrid beams presented similar stiffness, but the beams with added fibers showed greater ductility near the failure.

During the tests a good adherence was observed in the interface GFRP/concrete and the detachment between the profile and the concrete occurred only after the failure of the concrete, culminating in the mode of rupture previously described.

The addition of fibers to the concrete contributed to the increase of the failure load of the hybrid beams, due to the increase of the tensile strength of the concrete. Filling the profile of GFRP with concrete prevented the local buckling of the GFRP webs.

The vertical displacements in the center of the hybrid beams without and with the addition of fibers varied from L/101 (hybrid beams with $1 \%$ fibers with $35 \mathrm{~mm}$ long) to $\mathrm{L} / 51$ (hybrid beams with $1 \%$ fibers with $35 \mathrm{~mm}$ long), being $L$ the length of the span.

Figure 16 shows the cracking pattern of the concretes with and without fibers of the hybrid beams. It can be noted that the addition of polyolefin fibers reduced the opening of the cracks of the beams with $2.5 \%$ in volume of polyolefin fibers with $25 \mathrm{~mm}$ long and with $1 \%$ in volume of fibers with $35 \mathrm{~mm}$ long. Concretes with the

\section{Table 4}

Mean values of the concrete beams test results

\begin{tabular}{|c|c|c|c|c|c|c|}
\hline $\begin{array}{l}\% \text { of } \\
\text { fiber }\end{array}$ & $\begin{array}{l}\mathbf{P}_{\text {rup }} \\
(\mathrm{kN})\end{array}$ & $\begin{array}{c}\delta_{\text {rup }} \\
(\mathrm{mm})\end{array}$ & $\begin{array}{c}\sigma_{\text {sup }} \\
(\mathrm{MPa})\end{array}$ & $\begin{array}{c}\sigma_{\text {inf }} \\
(\mathrm{MPa})\end{array}$ & $\begin{array}{c}f_{\mathrm{cm}} \\
(\mathrm{MPa})\end{array}$ & $\begin{array}{c}f_{c t, s p} \\
\left(M^{\prime} P a\right)\end{array}$ \\
\hline 0 & 6.33 & 0.19 & 7.23 & 11.07 & 76.52 & - \\
\hline $\begin{array}{c}1 \\
25 \mathrm{~mm}\end{array}$ & 5.89 & 0.09 & 7.22 & 9.94 & 70.04 & - \\
\hline $\begin{array}{c}2.5 \\
25 \mathrm{~mm}\end{array}$ & 6.15 & 0.08 & 7.53 & 9.69 & 73.41 & 6.11 \\
\hline $\begin{array}{c}1 \\
35 \mathrm{~mm}\end{array}$ & 6.35 & 0.31 & - & - & 50.70 & 6.08 \\
\hline
\end{tabular}

\section{Table 5}

Hybrid beams test results

\begin{tabular}{ccccccc}
\hline $\begin{array}{c}\text { \% of } \\
\text { fiber }\end{array}$ & Beam & $\begin{array}{c}\mathbf{P}_{\text {rup }} \\
(\mathbf{k N})\end{array}$ & $\begin{array}{c}\mathbf{P}_{\text {rup med }} \\
(\mathrm{kN})\end{array}$ & $\begin{array}{c}\delta_{\text {rup }} \\
(\mathbf{m m})\end{array}$ & $\begin{array}{c}\varepsilon_{\text {rup sup }} \\
\mathbf{G F R P}\end{array}$ & $\begin{array}{c}\varepsilon_{\text {rup inf }} \\
\mathbf{G F R P}\end{array}$ \\
\hline 0 & MODRED2 & 36.92 & 37.1 & 6.03 & 0.0035 & 0.0046 \\
& MODRED3 & 37.31 & & 6.35 & 0.0032 & 0.0045 \\
$1-25 \mathrm{~mm}$ & MODRED3 & 37.80 & 37.5 & 7.17 & 0.0039 & 0.0044 \\
& MODRED4 & 37.13 & & 7.56 & 0.0027 & 0.0038 \\
$2,5-25 \mathrm{~mm}$ & MODRED6 & 39.14 & 40.5 & 7.24 & 0.0030 & 0.0055 \\
$1-35 \mathrm{~mm}$ & MODRED7 & 41.90 & 3.61 & 0.0042 & 0.0070 \\
\hline
\end{tabular}




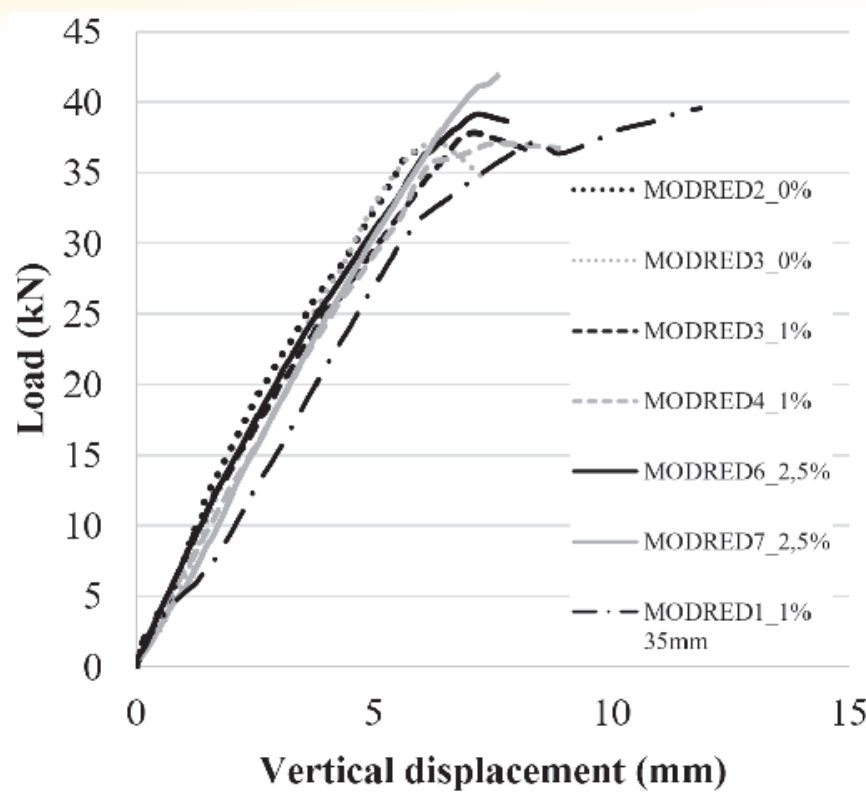

Figure 14

Load $x$ vertical displacement curves of the hybrid beams (Author)

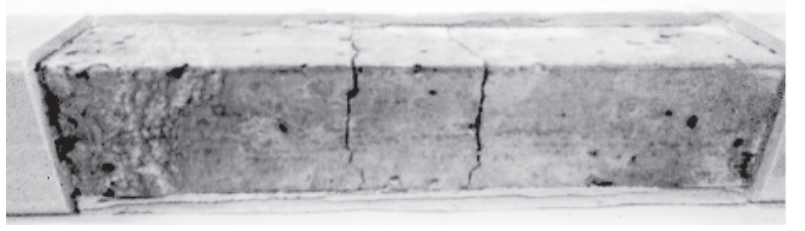

(a)
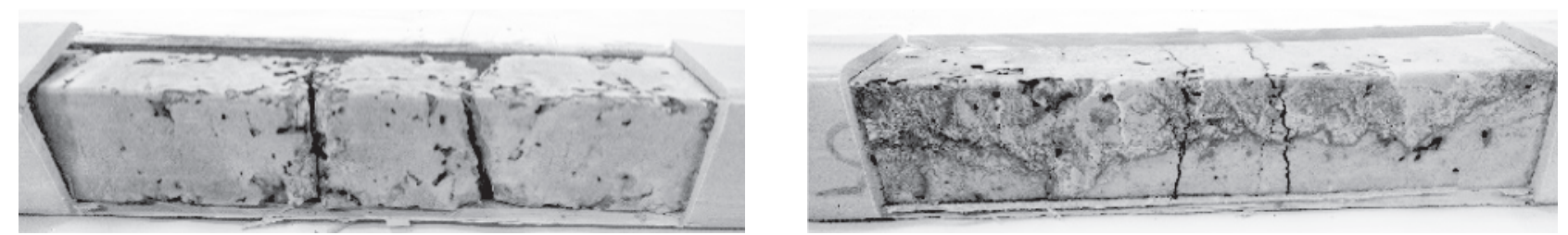

(b)
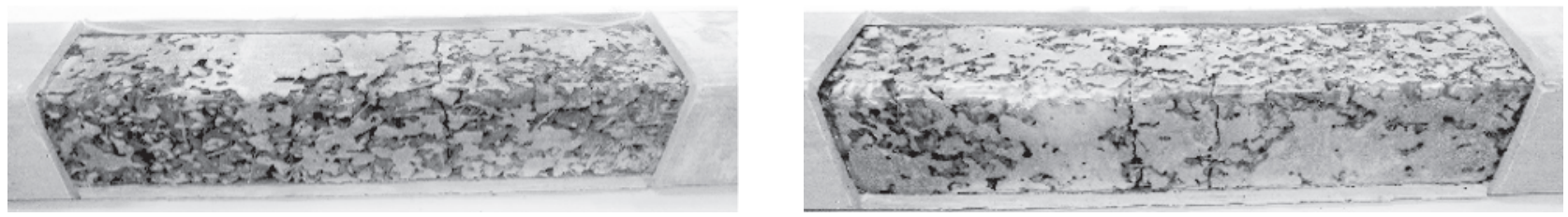

(c)

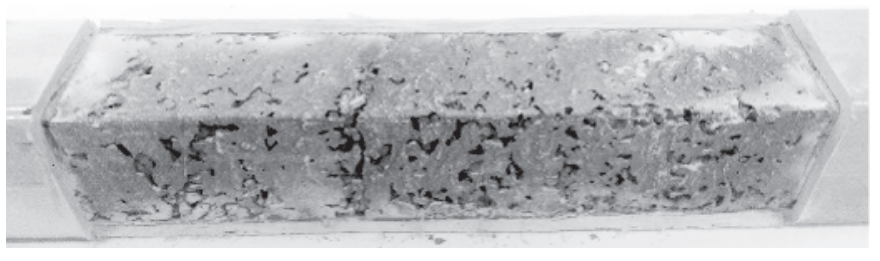

(d)

\section{Figure 16}

Concrete cracking of the hybrid beams: (a) without fibers, (b) with $1 \%$ fiber (25 mm), (c) with $2.5 \%$ fiber $(25 \mathrm{~mm})$ and $(\mathrm{d})$ with $1 \%$ fiber $(35 \mathrm{~mm}$ ) (Author) 
Table 6

Hybrid beams stress results

\begin{tabular}{cccc}
\hline $\begin{array}{c}\text { \% of } \\
\text { fiber }\end{array}$ & Beam & $\begin{array}{c}\sigma_{\text {rup sup }} \\
\text { GFRP }\end{array}$ & $\begin{array}{c}\sigma_{\text {rup inf }} \\
\text { GFRP }\end{array}$ \\
\hline \multirow{2}{*}{0} & MODRED2 & 80.80 & 106.20 \\
& MODRED3 & 82.03 & 115.35 \\
$1-25 \mathrm{~mm}$ & MODRED3 & 80.79 & 91.15 \\
& MODRED4 & 81.63 & 114.89 \\
$2,5-25 \mathrm{~mm}$ & MODRED6 & 84.23 & 154.41 \\
& MODRED7 & 91.53 & 152.56 \\
$1-35 \mathrm{~mm}$ & MODRED1 & 85.20 & 155.58 \\
\hline
\end{tabular}

Table 7

Results calculated from the hybrid beam tests results

\begin{tabular}{cccc}
\hline $\begin{array}{c}\% \text { of } \\
\text { fiber }\end{array}$ & Beam & $\begin{array}{c}\varepsilon_{\text {rup sup }} \\
\text { GFRP }\end{array}$ & $\begin{array}{c}\sigma_{\text {rup sup }} \\
\text { GFRP }\end{array}$ \\
\hline \multirow{2}{*}{0} & MODRED2 & 0.0028 & 93.70 \\
& MODRED3 & 0.0026 & 87.01 \\
$1-25 \mathrm{~mm}$ & MODRED3 & 0.0032 & 99.13 \\
& MODRED4 & 0.0022 & 68.15 \\
$2,5-25 \mathrm{~mm}$ & MODRED6 & 0.0023 & 87.31 \\
$1-35 \mathrm{~mm}$ & MODRED7 & 0.0033 & 125.28 \\
& MODRED1 & 0.0018 & 54.29 \\
\hline
\end{tabular}

addition of fibers also showed a greater number of voids. In none of the tests occurred the compressed concrete crushing.

A Table 6 displays the normal stress results on the upper and lower edges of the GFRP profile obtained from equation (7) and equation (8), respectively. These stresses were calculated from the bending moment and the neutral line position of the hybrid beam, equation (9), in the mid span section. The position of the neutral line was obtained from the strains of the GFRP profiles measured in the tests, despising the concrete in tension and considering an equivalent homogeneous section of the concrete.

$\sigma_{\text {supGFRP }}=\frac{M \cdot y}{I} \cdot n$

$\sigma_{\text {sup GFRP }}$ is the stress on the top edge of the GFRP profile;

$\mathrm{M}$ is bending moment;

$y$ is the height of the neutral line;

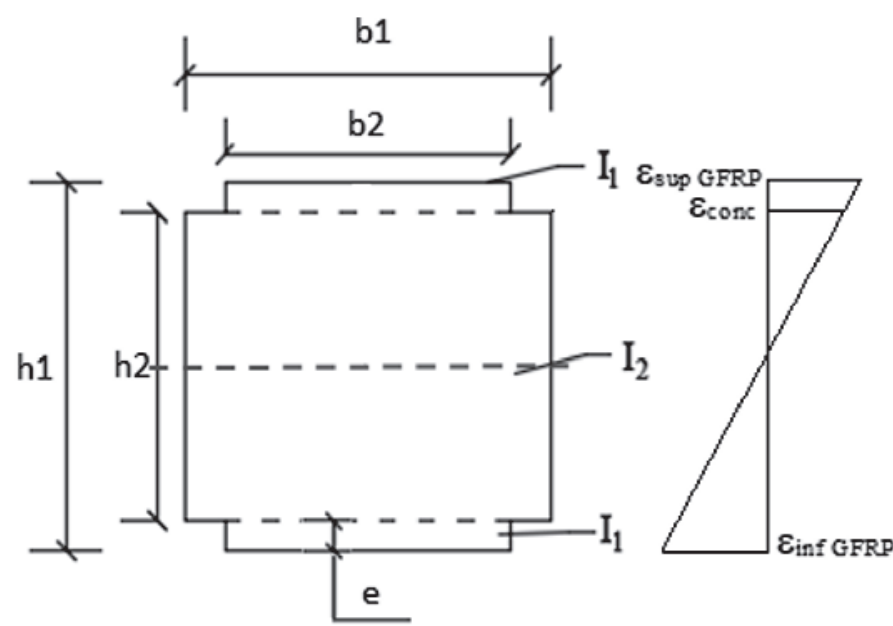

I is the moment of inertia of the equivalent homogeneous section of the concrete shown in Figure 17;

$\mathrm{n}$ is the relationship between the GFRP and concrete Young's modules.

$\sigma_{\text {infGFRP }}=\frac{M \cdot(h-y)}{I} \cdot n$

$\sigma_{\text {inf GFRP }}$ is the stress on the bottom edge of the GFRP;

$\mathrm{M}$ is bending moment;

$y$ is the height of the neutral line;

$h$ is the height of the profile;

$\mathrm{I}$ is the moment of inertia of the homogeneous equivalent section of the concrete shown in Figure 17.

$y=\frac{\varepsilon_{\text {SupGFRP }} \cdot b}{\varepsilon_{\text {supGFRP }}+\varepsilon_{\text {infGFRP }}}$

$y$ is the height of the neutral line;

$\varepsilon_{\text {supGFRP }}$ is strain on the upper edge of the GFRP profile;

$b$ is the width of the GFRP profile;

$\varepsilon_{\text {inf GFRP }}$ it is strain on the lower edge of the GFRP profile.

Table 7 presents the concrete strain and stress on the upper edge of the concrete in the hybrid beams, calculated according to the equations (10) and (11). It was assumed the perfect adherence between GFRP/concrete and the medium Young's modules obtained in the compressive tests (Table 3), except for the concrete with $1 \%$ fibers, in which only one result of Young's modulus was obtained.

$\varepsilon_{\text {conc }}=\frac{\varepsilon_{\text {sup GFRP. }}(y-e)}{y}$

$\varepsilon_{\text {conc }}$ is concrete strain;

$\varepsilon_{\text {sup GFRP }}$ is strain on the upper edge of the GFRP profile;

$y$ is the height of the neutral line;

$\mathrm{e}$ is the thickness of the GFRP profile.

$\sigma_{\text {conc }}=\frac{M \cdot y}{I}$

$\sigma_{\text {conc }}$ is concrete stress;

$\mathrm{M}$ is bending moment;

$y$ is the height of the neutral line;

$I$ is the moment of inertia of the equivalent homogeneous section of the concrete shown in Figure 17.

It is observed that the calculated concrete stresses approached the experiment concrete stresses obtained from the compression tests of cylindrical specimens. The mean tensile stresses on the

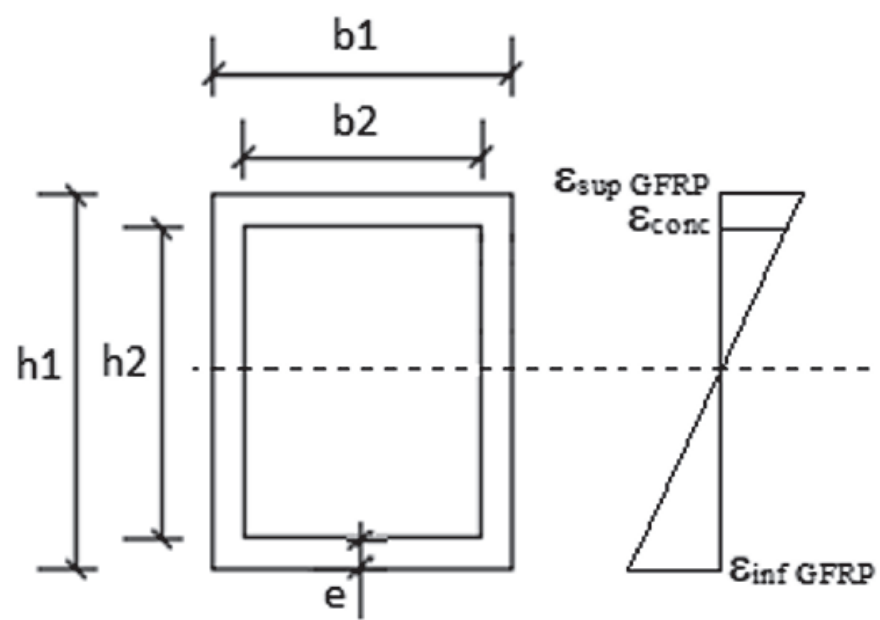

Figure 17

Equivalent homogeneous concrete section (Author) 
Table 8

$V_{c}$ values calculated for each volumetric percentage of fibers

\begin{tabular}{cccc}
\hline $\begin{array}{c}\text { \% of } \\
\text { fiber }\end{array}$ & $\mathbf{f}_{\mathrm{ctm}}$ & $\mathbf{f}_{\text {ctd }}$ & $\begin{array}{c}\mathbf{V}_{\mathrm{c}} \\
(\mathbf{k N})\end{array}$ \\
\hline 0 & 11.07 & 7.75 & 18.81 \\
$1-25 \mathrm{~mm}$ & 9.94 & 6.96 & 16.24 \\
$2,5-25 \mathrm{~mm}$ & 10.39 & 7.27 & 17.64 \\
$1-35 \mathrm{~mm}$ & 8.99 & 6.29 & 15.26 \\
\hline
\end{tabular}

GFRP profiles of the hybrid beams corresponded from $23.72 \%$ to $41.82 \%$ of the average tensile failure strength of strips of the GFRP profile (Table 2).

As previously reported, the failure of the GFRP profile of all hybrid beams occurred by shearing of the concrete, which is confirmed by calculating the portion of the shear force supported only by the concrete, $V_{c}$, by the equation (12) for each volumetric percentage of fibers. In the calculation it was considered $f_{\text {ctd }}$ being $70 \%$ of $f_{c t m}$ (Table 4 ) obtained from the tests of the concrete beams. The values of fctd and $V_{C}$ are presented in Table 8.

$V_{c}=0,6 \cdot f_{c t d} \cdot b_{w} \cdot d$

$\mathrm{V}_{\mathrm{C}}$ is shear force;

$b_{w}$ is the concrete width of the hybrid beams;

$d$ is the height of concrete of the beam.

It can be noticed that the shear forces of the hybrid beams, corre- sponding to $\mathrm{P}_{\text {rup }} / 2$ (Table 5) in bending tests, were very close to the portion of the shear force supported only by the concrete, ratifying the failure of the beam by shear.

\subsection{Prototype results}

Using the theory of the similarity of the physical models (Carneiro [14] and Teixeira [15]) and considering the tests results of the reduced models, one can estimate the failure values of load and vertical displacement and the masses of the sleepers in true grandeur, which are presented in the Tables 9, 10 and 11 .

It is observed that the increase in the fiber volume of the sleeper reduced the mass of it. Sleepers with $1 \%$ fibers of $25 \mathrm{~mm}$ long, $2.5 \%$ fibers of $25 \mathrm{~mm}$ and $1 \%$ of fibers of $35 \mathrm{~mm}$ long were $0.81 \%$, $6.68 \%$ and $10.16 \%$ lighter than the plain concrete sleepers. Compared to the prestressed concrete sleeper, the hybrid sleeper presented a weight reduction of $36.7 \%, 37.3 \%, 41.1 \%$ and $43.1 \%$, for plain concretes, $1 \%$ fibers of $25 \mathrm{~mm}, 2.5 \%$ fibers of $25 \mathrm{~mm}$ and $1 \%$ fibers of $35 \mathrm{~mm}$ long, respectively.

The failure loads estimated to the prototype were superior to the failure load of $120 \mathrm{KN}$ obtained by Bastos [2] in negative bending moment tests in the center of the concrete sleeper. The values were $114.3 \%, 116.4 \%, 134.2 \%$ and $128.6 \%$ higher than the failure load of the prestressed concrete sleeper, respectively, for plain concrete, $1 \%$ fibers of $25 \mathrm{~mm}, 2.5 \%$ fiber of $25 \mathrm{~mm}$ and $1 \%$ fiber of $35 \mathrm{~mm}$ hybrid sleepers. This happened even with the moment of inertia of the proposed hybrid sleeper corresponding to $41.6 \%$ of the moment of inertia of the usual prestressed concrete sleeper, whose cross section in the center of the sleeper is

\section{Table 9}

Specific weight and estimated mass of the sleeper prototypes

\begin{tabular}{|c|c|c|c|c|}
\hline \multirow{2}{*}{$\%$ de fiber } & \multirow{2}{*}{ Beam } & \multirow{2}{*}{$\begin{array}{c}\gamma_{\text {médio }} \\
\left(\mathrm{kN} / \mathrm{m}^{3}\right)\end{array}$} & \multicolumn{2}{|c|}{ Prototypes } \\
\hline & & & Mass (kg) & Mean mass $(\mathrm{kg})$ \\
\hline \multirow{2}{*}{0} & MODRED2 & \multirow{2}{*}{21,6} & 246,19 & 247,0 \\
\hline & MODRED3 & & 248,76 & - \\
\hline \multirow{2}{*}{$1-25 \mathrm{~mm}$} & MODRED3 & \multirow{2}{*}{21,4} & 246,92 & 245,0 \\
\hline & MODRED4 & & 241,77 & - \\
\hline \multirow{2}{*}{$2.5-25 \mathrm{~mm}$} & MODRED6 & \multirow{2}{*}{20,1} & 228,16 & 230,5 \\
\hline & MODRED7 & & 223,74 & - \\
\hline $1-35 \mathrm{~mm}$ & MODRED3 & 19,4 & 221,90 & 221,9 \\
\hline
\end{tabular}

\section{Table 10}

Prediction failure load of the sleeper prototypes

\begin{tabular}{cccc}
\hline \multirow{2}{*}{ \% de fiber } & \multirow{2}{*}{ Beam } & \multicolumn{2}{c}{ Prototypes } \\
\cline { 3 - 4 } & & $\mathbf{P}_{\text {rup }}(\mathbf{k N})$ & $\mathbf{P}_{\text {méd rup }}(\mathrm{kN})$ \\
\hline \multirow{2}{*}{0} & MODRED2 & 255.82 & 257.17 \\
& MODRED3 & 258.52 & \\
\multirow{2}{*}{$1-25 \mathrm{~mm}$} & MODRED3 & 261.95 & 259.63 \\
& MODRED4 & 257.31 & \\
\multirow{2}{*}{$2.5-25 \mathrm{~mm}$} & MODRED6 & 271.40 & 281.03 \\
$1-35 \mathrm{~mm}$ & MODRED7 & 290.65 & \\
\hline
\end{tabular}

Table 11

Vertical displacement on failure of the sleeper prototypes

\begin{tabular}{ccccc}
\hline \multirow{2}{*}{ \% de fiber } & \multirow{2}{*}{ Beam } & \multicolumn{2}{c}{ Prototypes } & \multirow{L}{L}{} \\
\cline { 3 - 4 } & & $\delta_{\text {rup }}(\mathrm{mm})$ & $\delta_{\text {méd rup }}(\mathrm{mm})$ & $\delta$ \\
\hline \multirow{2}{*}{0} & MODRED2 & 15.92 & 16.34 & $\mathrm{~L} / 98$ \\
& MODRED3 & 16.76 & & \\
\multirow{2}{*}{$1-25 \mathrm{~mm}$} & MODRED3 & 18.93 & 19.45 & $\mathrm{~L} / 82$ \\
& MODRED4 & 19.96 & & \\
\multirow{2}{*}{$2.5-25 \mathrm{~mm}$} & MODRED6 & 19.11 & 19.60 & $\mathrm{~L} / 82$ \\
& MODRED7 & 20.09 & & $\mathrm{~L} / 51$ \\
\hline
\end{tabular}


presented in Figure 18. The failure loads of the prototype were estimated by subtracting from the failure load of the reduced model the weight that had to be added to the same and multiplying the value obtained by the scale factor of the applied load. The additional load of the reduced model was calculated by the equation (13) and the prototype failure load was calculated by the equation (14). Table 12 presents the failure loads and the additional loads of the reduced model and the average loads estimated for the prototypes.

$P_{a d}=1,64 \cdot \gamma \cdot V_{\text {med }}$

\section{Table 12}

Additional load and failure load on the sleeper reduced models and prototypes (loading in the center of the sleeper)

\begin{tabular}{|c|c|c|c|c|c|c|}
\hline \multirow[b]{2}{*}{$\begin{array}{c}\% \text { of } \\
\text { fibres }\end{array}$} & \multirow[b]{2}{*}{ Beam } & \multicolumn{3}{|c|}{ Reduced model } & \multicolumn{2}{|c|}{ Prototype } \\
\hline & & $\begin{array}{l}P_{\text {rup }} \\
(\mathrm{kN})\end{array}$ & $\begin{array}{l}P_{\text {méd rup }} \\
(\mathrm{kN})\end{array}$ & $\begin{array}{l}\text { Additional } \\
\text { weight } \\
(\mathrm{kN})\end{array}$ & $\begin{array}{l}P_{\text {rup }} \\
(\mathrm{kN})\end{array}$ & $\begin{array}{c}P_{\text {méd rup }} \\
(\mathrm{kN})\end{array}$ \\
\hline \multirow{2}{*}{0} & MODRED2 & 36.92 & \multirow{2}{*}{37.12} & 0.215 & 255.82 & \multirow{2}{*}{257.17} \\
\hline & MODRED3 & 37.31 & & 0.218 & 258.52 & \\
\hline \multirow{2}{*}{$1(25 \mathrm{~mm})$} & MODRED3 & 37.80 & \multirow{2}{*}{37.46} & 0.216 & 261.95 & \multirow{2}{*}{259.63} \\
\hline & MODRED4 & 37.13 & & 0.211 & 257.31 & \\
\hline \multirow{2}{*}{$2.5(25 \mathrm{~mm})$} & MODRED6 & 39.14 & \multirow{2}{*}{40.52} & 0.199 & 271.40 & \multirow{2}{*}{281.03} \\
\hline & MODRED7 & 41.90 & & 0.197 & 290.65 & \\
\hline $1(35 \mathrm{~mm})$ & MODRED3 & 39.56 & 39.56 & 0.194 & 274.37 & 274.37 \\
\hline
\end{tabular}

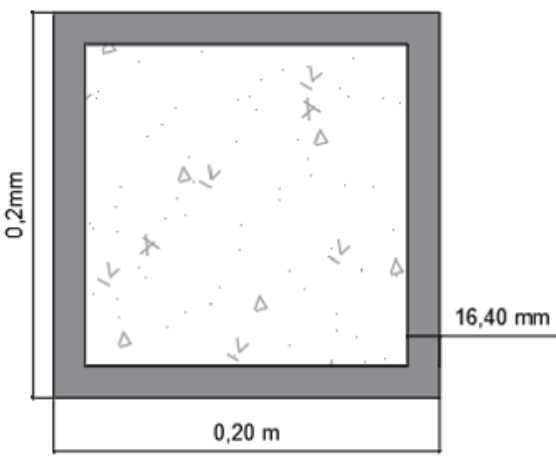

(a)

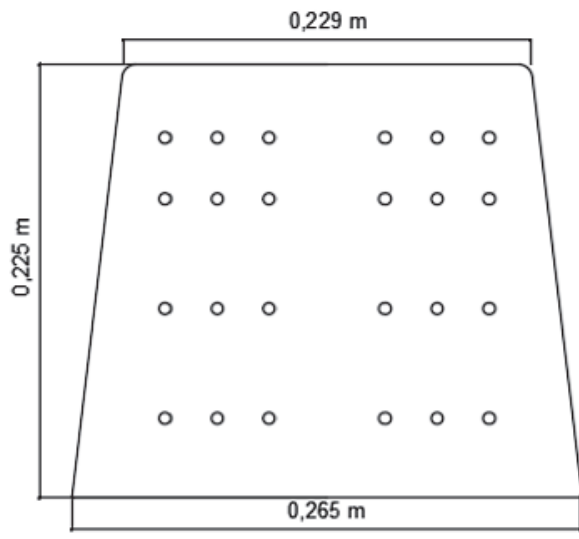

(b)

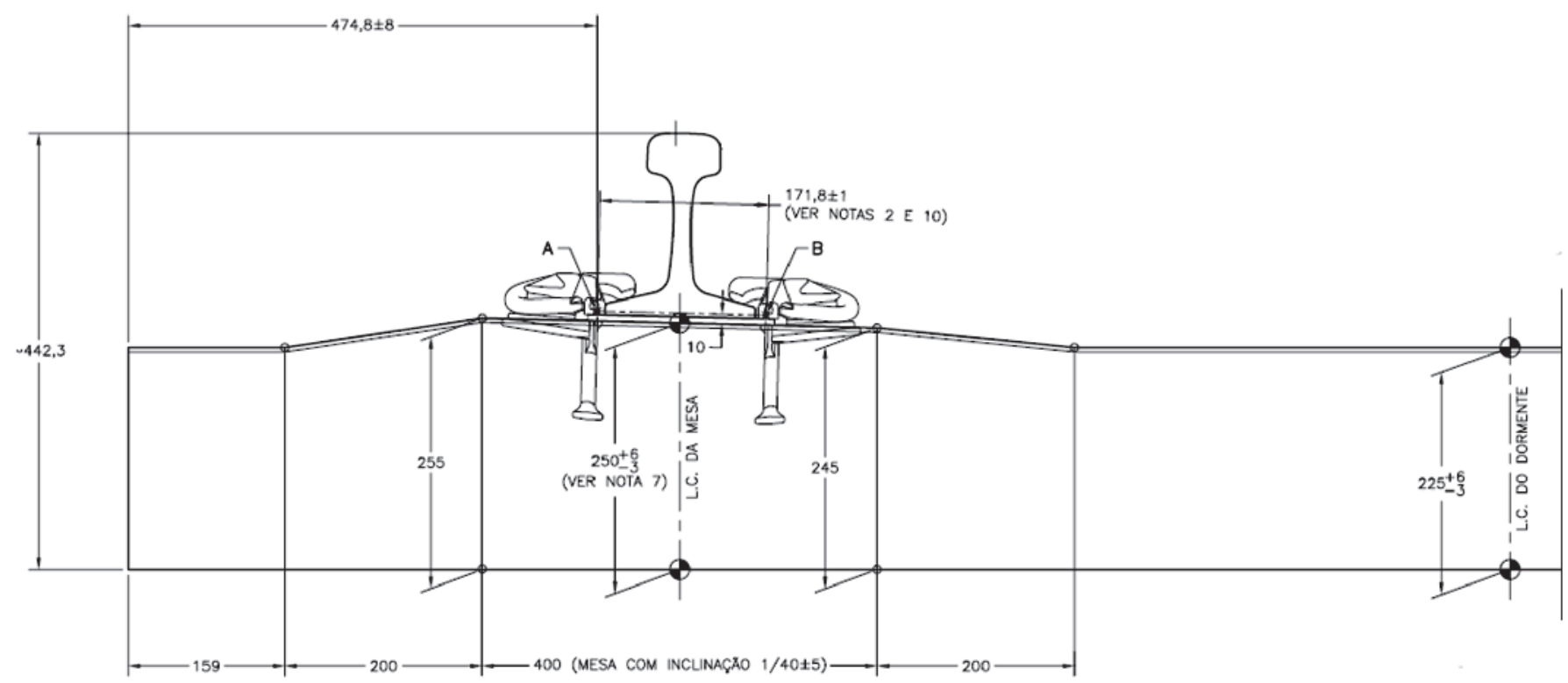

(c)

\section{Figure 18}

Transversal section in the center of the sleeper: (a) hybrid and (b) prestressed concrete and (c) half-view of the prestressed concrete sleeper DORBRÁS [19] 
$\gamma$ is specific weight of the hybrid beam;

$\mathrm{V}_{\text {med }}$ is the average volume of the prototype.

$P_{\text {rup prot }}=\left(P_{\text {rup mod }}-P_{a d}\right) \cdot 2,64^{2}$

$\mathrm{P}_{\text {rup mod }}$ is the reduced model failure load;

$P_{a d}$ is the additional load of the reduced model.

It should be emphasized that the dimensions of the cross section of the proposed hybrid sleeper $(200 \mathrm{~mm} \times 200 \mathrm{~mm}$ ) are lower than the usual prestressed concrete sleeper $(225 \mathrm{~mm} \times 265 \mathrm{~mm} \times 250$ $\mathrm{mm}$ - smaller base $\mathrm{x}$ larger base $\mathrm{x}$ height).

The average failure vertical displacement estimated for sleeper prototypes varied from $L / 51$ to $L / 82$. These values were lower than the L/41 value obtained by Muttashar [16], indicating a good performance of the proposed hybrid sleeper.

\section{Conclusion}

The addition of fibers to the concrete increased a little the failure load of the beams and allowed greater tensile stresses on the lower edge of the GFRP profile, suggesting greater elongation of the concrete with fibers in relation to the plain concrete until the failure. The addition of polyolefin fibers also contributed to the reduction of the widths of the cracks on the concretes with $2.5 \%$ by volume of fibers of $25 \mathrm{~mm}$ long and $1 \%$ by volume of fibers of $35 \mathrm{~mm}$ long. In the tests with loading at the center of the sleeper, the failure of all the hybrid beams occurred on the lower edge of the hybrid sleeper due to the rupture of the concrete by shear followed by the rupture of the GFRP profile parallel to the fibers. In none of the tests occurred the rupture of the compressed concrete.

The vertical displacements at the proposed sleeper ranged from $L / 101$ to $L / 51$, having been slightly lower than the values obtained by Gibson [5] and approaching the values obtained for wood sleepers, as mentioned by this same author.

The sleepers proposed with $1 \%$ fibers of $25 \mathrm{~mm}, 2.5 \%$ fibers of $25 \mathrm{~mm}$ and $1 \%$ of fibers of $35 \mathrm{~mm}$ long were $0.81 \%, 6.68 \%$ and $10.16 \%$ lighter than the plain concrete sleeper, respectively. The average failure loads of the hybrid sleepers were $114.3 \%, 116.4 \%$, $134.2 \%$ and $128.6 \%$ higher than the failure load of the prestressed concrete sleeper, respectively, for plain concrete, $1 \%$ fibers of 25 $\mathrm{mm}, 2.5 \%$ fibers of $25 \mathrm{~mm}$ and $1 \%$ fibers of $35 \mathrm{~mm}$ long on the negative bending moment tests in the center of the sleeper.

Finally, it can be concluded that the performances of the sleepers proposed were quite satisfactory in terms of strength and weight, comparing with prestressed concrete sleepers, being a technical viable alternative. As recommendation for future works, the authors suggest the conduction of fatigue tests and tests of a true grandeur hybrid sleeper.

\section{References}

[1] PLANETA FERROVIA - Bitolas Ferroviárias, 2014. Available in: http://planetaferrovia.blogspot.com/2014/01/bitolas-ferroviarias.html., Access in July 2018.

[2] BASTOS, S, S, Análise experimental de dormentes de concreto protendido reforçado com fibras de aço, Tese de Doutorado, Escola de Engenharia de São Carlos, São Carlos, SP, Brasil, 1999.

[3] TRINDADE, E. J. Análise sobre a utilização de dormentes de concreto como solução alternativa para a via permanente na MRS Logística S. A. Trabalho Final de Curso, Programa de Especialização de Transporte Ferroviário, Instituto Militar de Engenharia, Rio de Janeiro, 2012.

[4] DEPARTAMENTO NACIONAL DE INFRAESTRUTURA DE TRANSPORTES - DNIT, PIM - Procedimento de Inspeção de Material, Dormente de Aço para Via Férrea. Available in: www.dnit.gov.br/...e...para.../PIM\%20016\%20-\%20Dormente\%20de\%20Aço.pdf, acesso em abril de 2018.

[5] GIBSON, R. F., Principles of Composite Material Mechanics, Ed, McGraw-Hill, 1994.

[6] FERDOUS, W., KHENNANE, A., KAYALI, O., Hybrid FRPconcrete railway sleeper, University of 'New South Wales, Canberra, Australia, 2013.

[7] MUtTASHAR, M., MANOLO, A., KARUNASENA, W., LOKUGE, W., Influence of infill concrete strength on the flexural behaviour of pultruded GFRP square beams, Composite Structures, v. 145, p. 58-67, 2016.

[8] MUTTASHAR, M., MANOLO, A., KARUNASENA, W., LOKUGE, W., Flexural behaviour of multi-celled GFRP composite beams with concrete infill: Experiment and theoretical analysis, Composite Structures, v. 159, p. 21-33, 2017.

[9] GASPAR, D. H., CARNEIRO, L. A. V., TEIXEIRA, A. M. A. J., Estudo de placas de concreto com fibras de aço e de poliolefina submetidas a impacto balístico. REVISTA MILITAR DE CIÊNCIA E TECNOLOGIA, v. XXXIII, p. 57-62, 2016.

[10] ALBERTI, M. G., ENFADAQUE, A., GÁLVEZ, J.,C., AGRAW$A L, V$., Reliability of polyolefin fibre reinforced concrete beyond laboratory sizes and construction procedures, Composite Structures, v. 140, p. 506-524, 2016.

[11] ALBERTI, M. G., ENFADAQUE, A., GÁLVEZ, J. C., AGRAW$A L, V$., Fibre distribution and orientation of macro-synthetic polyolefin fibre reinforced concrete elements, Construction and Building Materials, v. 122, p. 505-517, 2016.

[12] ASSOCIAÇÃO BRASILEIRA DE NORMAS TÉCNICAS. Dormente de concreto - Projeto, materiais e componentes. NBR 11709, Rio de Janeiro, 2015.

[13] AMERICAN RAILWAY ENGINEERING AND MAINTENANCE ASSOCIATION. Manual for Railway Engineering Concrete Ties. - AREMA, v.1, cap 30, 2016.

[14] CARNEIRO, F. L., Análise dimensional e teoria das semelhanças e dos modelos físicos, Rio de Janeiro, Editora UFRJ, 256p, 1996.

[15] TEIXEIRA, A. M. A. J., Ponte desmontável em material compósito de fibra de vidro, Tese de D.Sc., COPPE/UFRJ, Rio de Janeiro, RJ, Brasil, 2007.

[16] AMERICAN SECTION OF THE INTERNATIONAL ASSOCIATION FOR TESTING MATERIALS. Standard Test Methods for Rubber Products - Chemical Analysis. - ASTM D297, Philadelphia, PA, 2013.

[17] AMERICAN SECTION OF THE INTERNATIONAL ASSOCIATION FOR TESTING MATERIALS. Standard Test Method for Tensile Properties of Polymer Matrix Composite Materials. - ASTM D3039/D3039M, Philadelphia, PA, 2008.

[18] ASSOCIAÇÃO BRASILEIRA DE NORMAS TÉCNICAS, NBR 5739: Concreto - Ensaio de compressão de corposde-prova cilíndricos, Rio de Janeiro, 1994. 
[19] COMPANIA BRASILEIRA DE DORMENTES - DORBRÁS. Available in: http://dorbras.com.br. Acesso em agosto 2016.

[20] MUNDO DAS TRIBOS, Dormente de Madeira. Rio de Janeiro. Available in: <http://www.mundodastribos.com/dormentes-de-madeira-precos.html> Acesso em jan de 2017.

[21] PANDROL, Track Report, France, 1996, Available in: http:// www.pandrol.com/download/pandrol-track-report-1996/. Acesso em: maio de 2017. 